$\overline{\text { 原 著 }}$

\title{
言語訓練患者の訓練中にみられた血圧変動について
}

\author{
谷 哲夫 ${ }^{1)}$ 長谷川靖英 ${ }^{1)}$ 斎藤 ゆき1) 中島 洋巳 ${ }^{1)}$ \\ 坂本浩之助 ${ }^{2)}$ 菅井 芳郎 ${ }^{3)}$
}

\begin{abstract}
要 約: 本研究では, WAB 失語症検査ほか当院で実施している検査指標を用い, 言語訓練中 に血圧が上昇する患者と上昇しない患者の比較をした。 [対象]対象は, 沢渡温泉病院にて言語 療法を受けている脳卒中患者 21 例である. [方法]患者を訓練室の隣室にて 30 分間安静にさせ, ついで, 言語療法室に入室させ, 約 30 分間の訓練を開始した。 その後再び患者を隣室に戻し安 静にさせた。この間, 患者の上腕に血圧測定装置を装着し, 血圧・脈拍を 2 分間隔で測定した. [結果] WAB 失語症検查の得点率を比較すると, 言語課題では流暢性を除いた全課題で血圧上 昇群の得点率が非上昇群より有意に高くなった。コミュニケーションレベル評価においては, 理解系で上昇群のほうが軽症であったが, 表出系では両群の間に差がなかった. [考察] 頭言 語の流暢性にかかわらず, コミュニケーション理解能力が保たれている患者ほど言語訓練中に 血圧上昇を呈しやすいことが考えられた。
\end{abstract}

索引用語：血圧上昇, 言語療法, 脳卒中後, コミュニケーション能力

\section{Increased Blood Pressure During Speech Therapy in Patients with Language Disorder}

\author{
Tetsuo Tani ${ }^{1)}$, Yasuhide Hasegawa ${ }^{1)}$, Yuki Saito ${ }^{1)}$, \\ Hiromi Nakajima ${ }^{1)}$, Hironosuke Sakamoto ${ }^{2)}$, Yoshiro Sugai ${ }^{3)}$
}

\begin{abstract}
Ambulatory blood pressure (BP) monitoring at two-minute intervals was performed during speech therapy in 21 post-stroke language disorder patients (aged 44 to 74 years, mean 61.3 years ; 12 male and 9 female). The patients included global aphasia $(n=1)$, Brocaf's aphasia $(n=5)$, Werniche's aphasia $(n=4)$, mixed aphasia $(n=7)$, amnesic aphasia $(n=2)$, conduction aphasia $(n=1)$, and aphemia $(n=1)$. Thirteen $(62 \%)$ of the patients exhibited a significant increase in systolic BP during speech therapy, which we termed the "increased BP group". Scores of the Western Aphasia Battery profiles were compared between the increased and the non-increased BP groups. Patients in the increased BP group had a significantly higher score in all subtests except fluency and composition than patients in the non-increased BP group. Communicative ability of recep-

\footnotetext{
1)群馬県医師会沢渡温泉病院言語療法室, ${ }^{3)}$ 同 内科： $\mathbf{T} 377-05$ 群馬県吾妻郡中之条町大字上渡 2136

2)群馬大学医学部第 2 内科教室： $\mathbf{T} 371$ 前橋市昭和町三丁目 39-22

${ }^{11}$ Speech Therapy Section, ${ }^{3}$ Department of Internal Medicine, Sawatari Spa Hosital : 2136 Nakanojo-machi Agatsuma-gun, Gunma 377-05

${ }^{2}$ Second Department of Internal Medicine, Gunma University School of Medicine : 3-39-22 Showa-machi Maebashi-shi, Gunma 371

原稿受理：1996 年 12 月 17 日
} 
tivity was well preserved in the increased BP group, but not in the non-increased BP group. Ability of expression was similar in both groups. These results indicate that patients with well-preserved receptivity exhibit a more exaggerated pressor response to speech therapy, and that it is important for speech therapists to monitor BP during speech therapy.

Key words : blood pressure, speech therapy, post-stroke, communicative ability

\section{はじめに}

言語訓練を受ける患者の中には，理学療法を含むり ハビリテーションの中で, 言語訓練が最も疲労すると 訴えるものが少なくない. 図 1 は，そのような訴えの あった重篤な発語失行症患者の血圧・脈拍変動である. これによると，訓練中に血圧が著しく上昇し，収縮期 血圧が安静時平均 $119 \mathrm{mmHg}$ から最大 $186 \mathrm{mmHg}$ ま で上昇 $(56 \%)$ しており，言語訓練そのものが強いス トレスになっていることがうかがえる，数日後に同様 の血圧測定を行ったが，やはり訓練中に著しい血圧上 昇がみられ, 血圧変動の再現性が確認された。本症例 では脈拍数が安静時から少なく, 訓練中にもほとんど 増加していない。これは，狭心症および心房細動の治 療のために服用していた $\beta$ 遮断薬の作用によるもの と考えられる．加瀬田ら（1995）は，言語障害患者の 訓練時のストレスについて, 24 時間血圧計を患者に装 着させて血圧・心拍数と不整脈を指標にして調査した. 訓練中および日常生活時の心拍数と血圧の平均値, 夜 間睡眠安静時の平均值との比をとり，その比をストレ ス指数としたところ, 麻痺度, ADL 指数と日中活動時 ストレス指数との間に相関はなく, 14 例中 7 例で言語
訓練時にストレス指数が最大であり，9例で日中活動 時より言語訓練時のほうがストレス指数は大きかっ た。

本研究では, WAB (The Western Aphasia Battery) 失語症検查（日本語版，杉下 1986） ほか当院で実施 している検査指標について，言語訓練中に血圧が上昇 する患者と上昇しない患者の比較をすることにより， 言語訓練中の血圧上昇に注意すべき患者像を明らかに しょうとした。

\section{対 象}

沢渡温泉病院に入院して言語療法を受けている脳卒 中患者 21 例 (男 12 例，女 9 例，年歯 $44 \sim 74$ 歳，平均 年齢 62 歳, 発症経過 63〜1725 日，平均 414 日）を対 象とした。脳卒中の種類は出血 11 例, 梗塞 10 例であ った，言語障害の種類は，全失語 1 例，ブローカ失語 5 例, ウェルニッケ失語 4 例, 混合失語 7 例, 伝導失 語 1 例, 健忘失語 2 例, 発語失行 1 例であった。

\section{方法}

血圧測定検査は, 入院後 2 力月以上が経過し, 患者 が言語療法士に慣れたころに次の手順で実施した。ま

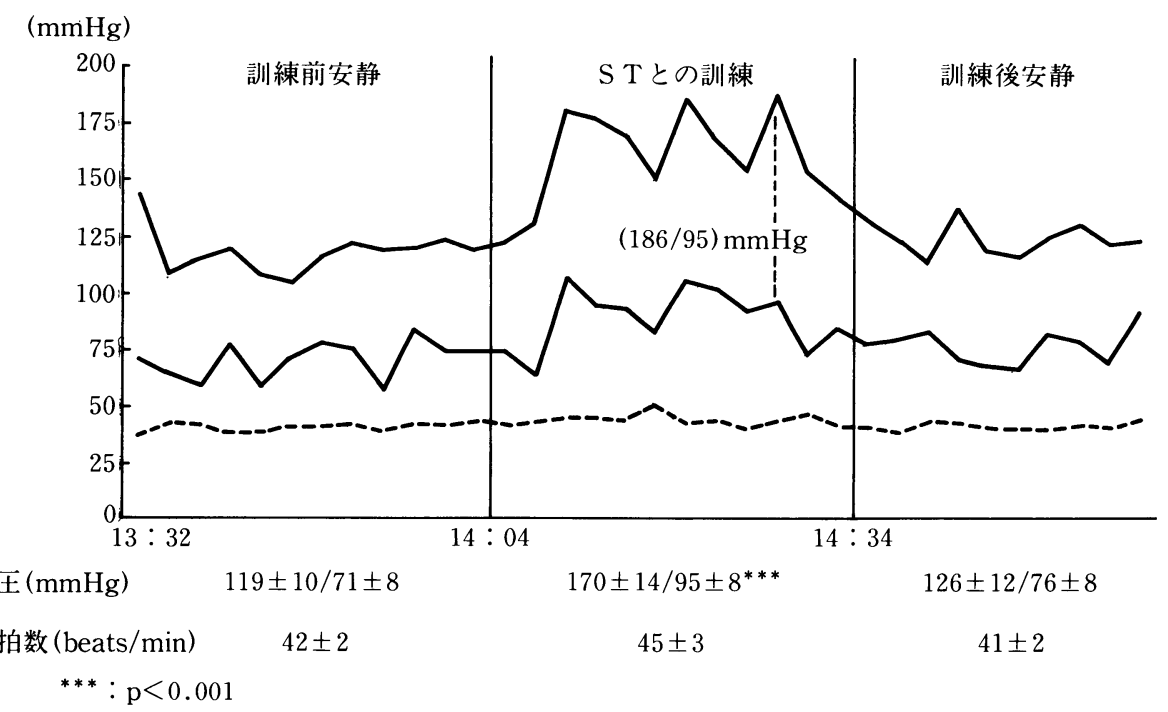

図 1 言語訓練に対して疲労を訴えた 1 脳血管障害患者の血圧・脈拍変動 


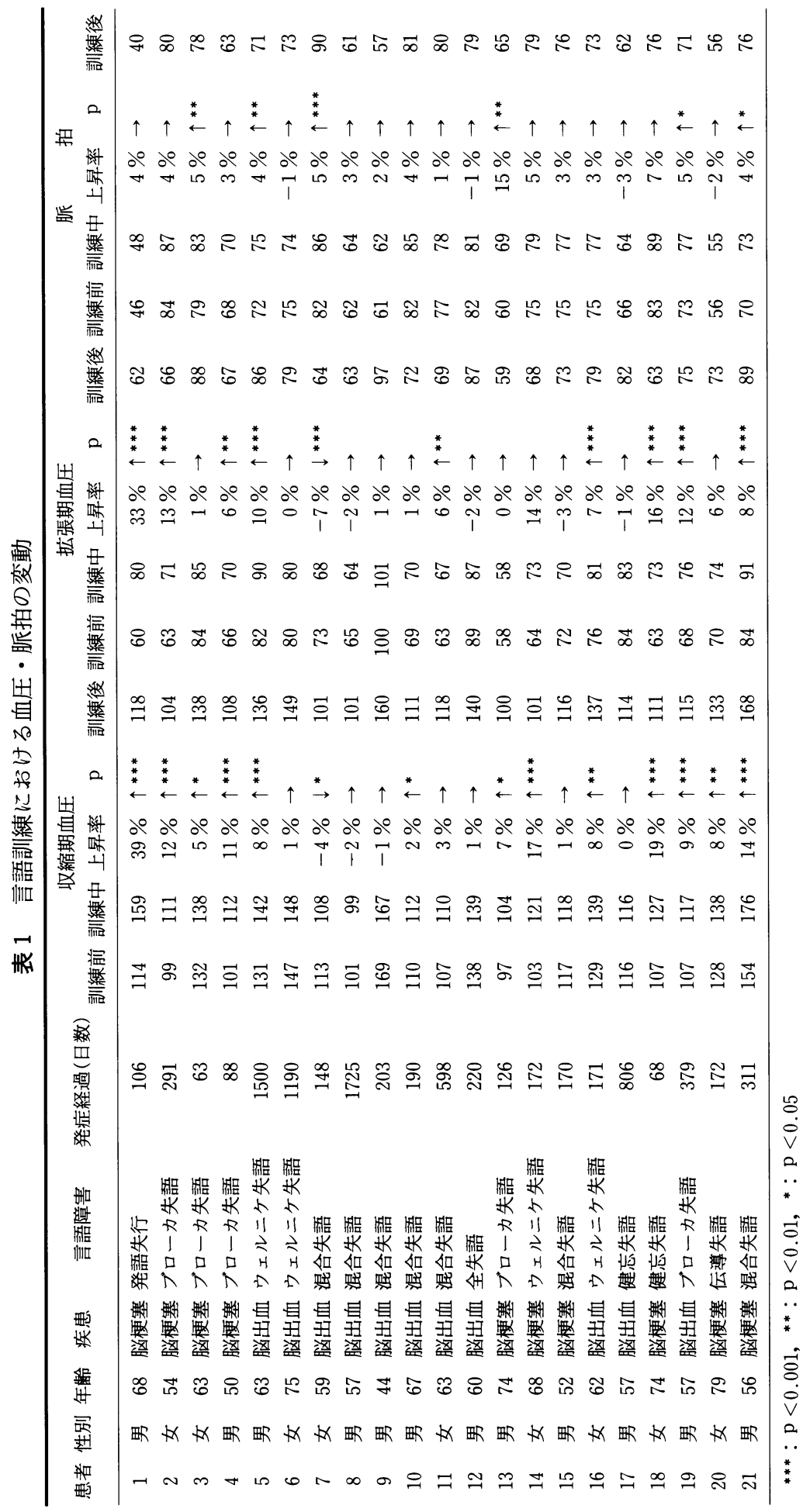


表 2 血圧測定時の各臨床指標の比較

\begin{tabular}{lccl}
\hline \multicolumn{1}{c}{ 項目 } & 上昇群 $(\mathrm{n}=13)$ & 非上昇群 $(\mathrm{n}=8)$ & \multicolumn{1}{c}{$\mathrm{p}$} \\
\hline 性別（男 vs 女) & 7 vs 5 & 5 vs 3 & N. S. \\
年齢 & $64.2 \pm 8.6$ & $58.4 \pm 8.9$ & N. S. \\
疾患（梗塞 vs 出血） & 9 vs 4 & 1 vs 7 & $\mathrm{p}<0.5$ \\
発症経過（日数） & $280 \pm 379$ & $633 \pm 578$ & N. S. \\
高血圧 & $5 / 13(38 \%)$ & $5 / 8(63 \%)$ & N. S. \\
糖尿病 & $3 / 13(23 \%)$ & $1 / 8(12 \%)$ & N. S. \\
流暢型（流暢 vs 非流暢) & 5 vs 8 & 3 vs 5 & N. S. \\
飲酒歴 & $7 / 13(54 \%)$ & $4 / 8(50 \%)$ & N. S. \\
喫煙歴 & $6 / 13(46 \%)$ & $3 / 8(37 \%)$ & N. S. \\
\hline
\end{tabular}

ず, 患者を訓練室の隣室にて座位にて 30 分間安静にさ せた。ついで，言語療法室に入室させ，約 30 分間の訓 練を開始した。その後再び患者を隣室に戻して 30 分間 安静にさせた。この間, 患者の健側の上腕に血圧測定 装置（日本コーリン社製 ABPM-630）を装着し，血圧 を 2 分間隔で測定した。この記録をもとに，血圧につ いて, 訓練前 30 分, 訓練中 30 分, 訓練後 30 分の 3 区 間ごとに各 15 回の測定值の平均を算出した. 訓練内容 は, 呼称や音読, 復唱といった口頭表出の訓練を中心 に行った. 統計学的検討には, 有意水準 $5 \%$ 末満をも って有意差ありと判定し, 分散分析に F-test を行い, 差があれば Welch's t-testを, 差がなければ Student' s t-test を用いた.クロス集計の解析には chi-square test for independence を用いた。

\section{結果}

患者別の収縮期血圧の変化は, 上昇 13 例, 不変 7 例, 下降 1 例であった（表 1 ）。血圧上昇群 13 例と非上昇 群 8 例とに分けて各種臨床指標を比較したところ, 性 別, 年齢, 発症から血圧測定までの経過日数, 高血圧 の有無，糖尿病の有無などは両群間で差がなかった。 また，失語タイプを口頭言語の流暢型と非流暢型に分 けて，その比率が両群間で異なるかを検討したが, 差 はなかった。一方, 疾患の種類では両群間に有意の差 がみられた。すなわち, 血圧上昇群では脳梗塞が多か ったのに対し,非上昇群では脳出血が多かった(表 2 ). ただし，頭部 CT 上認められる病巣の部位や大きさで 両群の間に差異を見い出すことはできなかった. 血液 検査成績, 胸部 $\mathrm{X}$ 線, 心電図所見は, 両群間で差がな かった.

\section{WAB 失語症検査の得点率}

$\mathrm{WAB}$ 失語症検査の得点率を検討すると, 言語課題 では，流暢性を除いた全課題で血圧上昇率が有意に高 くなった(上昇群 vs. 非上昇群. 情報の内容 $6.6 \pm 2.6$
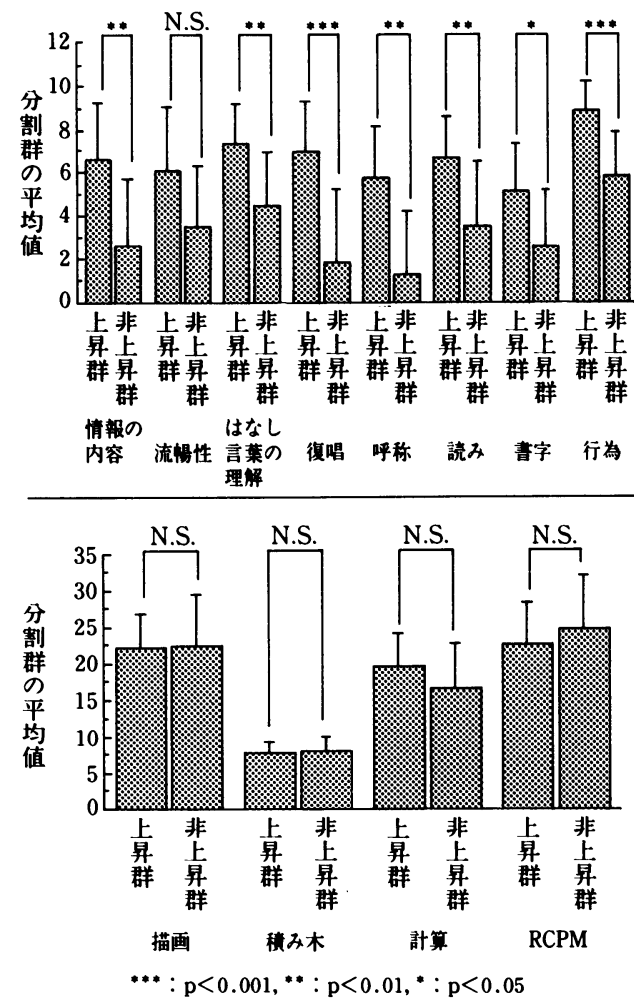

図 $2 \mathrm{WAB}$ 失語症検査の得点率.上段が言語課題, 下段が非言語課題

vs. $2.6 \pm 3.1$, 流暢性 $6.1 \pm 3$ vs. $3.5 \pm 2.8$, 話し言葉 の理解 $7.3 \pm 1.8$ vs. $4.5 \pm 2.4$, 復唱 $6.9 \pm 2.4$ vs. $1.8 \pm 3.4$, 呼称 $5.8 \pm 2.4$ vs. $1.2 \pm 3$, 読み $6.7 \pm 1.9$ vs. $3.5 \pm 3$, 書字 $5.2 \pm 2.2$ vs. $2.6 \pm 2.6$, 行為 $8.9 \pm$ 1.3 vs. $5.9 \pm 2$ 図 2 上段).

非言語課題である構成課題の得点率は両群間で差は なかった（上昇群 $7.5 \pm 1.2$ vs. 非上昇群 $7.2 \pm 1.6$, 内 訳. 描画 $22.3 \pm 4.5$ vs. $22.5 \pm 2.5$, 積み木 $7.7 \pm 1.5$ vs. $8 \pm 2.1$, 計算 $19.5 \pm 4.5$ vs. $16.8 \pm 5.9$, Reaven 
表 3 コミュニケーションレベル評価基準

\begin{tabular}{|c|c|c|c|}
\hline & レベル & WAB 失語症検査得点率 & 症状 \\
\hline 理解系 & レベル 1 & $81 \sim 100 \%$ & 質問や指示の理解に問題はない \\
\hline \multirow{4}{*}{$\begin{array}{l}\text { 話し言葉の理解 } \\
\text { 読み }\end{array}$} & レベル 2 & $61 \sim 80 \%$ & 質問や指示にたいしてときどき誤った行動や返答をする \\
\hline & レベル 3 & $41 \sim 60 \%$ & 簡単な指示や質問ならばほとんど理解する \\
\hline & レベル 4 & $21 \sim 40 \%$ & 簡単な指示や質問にたいして多少誤りがある \\
\hline & レベル 5 & $0 \sim 20 \%$ & 簡単な指示や質問にたいして誤りが多い \\
\hline \multirow{5}{*}{$\begin{array}{l}\text { 表出系 } \\
\left(\begin{array}{l}\text { 自発話 } \\
\text { 呼称 }\end{array}\right.\end{array}$} & レベル 1 & $81 \sim 100 \%$ & 発話能力に問題はない \\
\hline & レベル 2 & $61 \sim 80 \%$ & 健忘や構音障害のために聞き手の多少の配慮が必要 \\
\hline & レベル 3 & $41 \sim 60 \%$ & 発話に書字・身振りを加えかつ聞き手の配慮が必要 \\
\hline & レベル 4 & $21 \sim 40 \%$ & 多少の発話はあるが Yes-No 反応主体 \\
\hline & レベル 5 & $0 \sim 20 \%$ & Yes-No 反応もできない \\
\hline
\end{tabular}

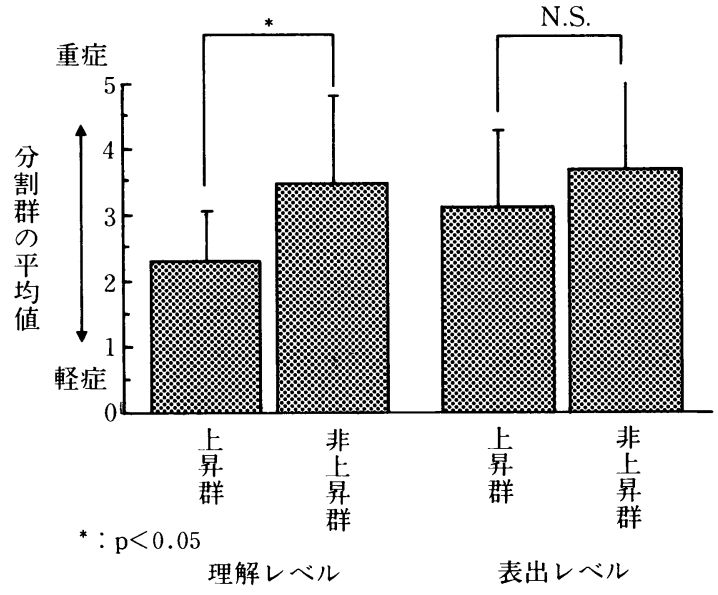

図３コミュニケーションレベル評価

色彩マトリックス $22.6 \pm 5.7$ vs. $24.6 \pm 7.4$ 図 2 下 段)。また積み木と Reaven 色彩マトリックス課題にお ける所要時間(積み木：上昇群 1 分 44 秒 \pm 43 秒 vs. 非 上昇群 2 分 33 秒土 1 分 53 秒, Reaven 色彩マトリッ クス：上昇群 9 分 46 秒土 3 分 45 秒 vs. 非上昇群 13 分 20 秒土 7 分 18 秒）にも両群間で差はなかった。

\section{2.コミュニケーション・レベル評価}

当院では, 評価の中に, コミュニケーションレベル という指標を設けている。これは，ある程度 WAB 検 查の結果をもとにしながら，検查結果の数值だけでは 検出しにくい, 患者の状況判断力, 適応力などを含め た総合的なコミュニケーション能力を観察的に評価す るもので, 理解系レベルと表出系レベルに分けている. 評価基準は表 3 に示すとおりで, WAB 失語症検査の 理解系（話し言葉の理解, 読み) と表出系 (自発話, 復唱, 呼称, 書字) の得点率を参考にし, 最も軽症な
レベル 1 から最も重症なレベル 5 までの 5 段階評価を 実施するものである.

このコミュニケーションレベル評価においては，理 解系レベルで血圧上昇群のほうが軽症 (上昇群 : $2.3 \pm$ 0.8 vs. 非上昇群 $: 3.5 \pm 1.3)$ であったが, 表出系レべ ルでは両群間に差はなかった（上昇群：3.2+1.1 vs. 非上昇群: $3.8 \pm 1.5$ 図 3 ).

\section{考察}

われわれは当初, 非流暢性言語障害の患者のほうが, 言語訓練にストレスを感じやすく血圧が上昇しやすい と予想した. しかし, 本研究の結果からは, 流暢性か 非流暢性かにかかわらず，状況理解力などを含めた総 合的なコミュニケーション能力がよく保たれている患 者ほど言語訓練中に血圧が上昇しやすいということが 明らかになった。 反対に，コミュニケーション理解能 力が強く障害されている患者は状況判断力が低下して おり，言語訓練に対する緊張が起きず，血圧があまり 上昇しないと考えられる。

次に, 構成課題の下位検査をみると, Reaven 色彩マ トリックス, 描画, 計算, 積み木, の非言語課題にお ける両群の得点には差がなかった。この結果は, 非言 語能力が言語障害と分離しやすい性質がある（杉下 1985，小俣ら 1989）ことを示している.しかし，ST が観察的に評価するコミュニケーションレベルの理解 系で差が認められたことを考慮すると, WAB 失語症 検査における非言語課題の成績は，かならずしも状況 判断・理解能力を正確に評価していない可能性がある.

心理的ストレスにより血圧・心拍数が上昇すること は確かであり，その程度は高血圧者で大きいことはよ く知られている (Sakamoto H ら 1992, 坂本 1993, 菊地ら 1994,)。しかし, 大畠ら（1993，1995）は脳 
血管障害患者を高血圧群と非高血圧群とに分類し, 言 語負荷を実施したところ，急性期では高血圧群で血圧 の上昇が認められたものの, 慢性期では両群とも顕著 な変化はなかった。本研究で対象とした患者はすべて 慢性期であり, 血圧上昇群と非上昇群とで高血圧の有 病率に差はなかったことは, 大畠らの報告と一致した。

近年，白衣を着た医師を前にすると精神的に緊張状 態になるため, 交感神経活性が亢進して血圧が上昇し やすくなる，いわゆる白衣現象（芦田 1993）が，言 語療法士を前にした言語訓練患者に観察されたとの報 告があった（持田ら 1994, 坂本ら 1995). 坂本ら （1995）は，言語療法を受けている脳卒中患者の血圧・ 心拍数を測定し, その変動様式を言語療法士との対面 訓練と自主訓練とで比較したところ, 言語療法士を前 にしたときのほうが血圧上昇が著しい，白衣現象を観 察しえた。しかも，白衣現象を呈する患者の臨床像を $\mathrm{WAB}$ 失語症検查で検討したところ，言語障害の種類 によらず，理解力がよく保たれた患者ほど言語療法士 と向き合ったときに緊張しやすく，血圧が上昇したと いうことであった。この研究結果は，本研究での血圧 上昇群がコミュニケーション理解能力のよく保たれて いる患者であったことと一致する.

持田ら（1994）によれば，言語訓練中に収縮期血圧 が $200 \mathrm{mmHg}$ を持続的に越えるようなら, 降圧療法の 検討が必要であるという。本研究において観察された 言語訓練中の血圧上昇群の患者には, 訓練中の収縮期 血圧が $200 \mathrm{mmHg}$ を越える者はいなかった.しかし， 血圧の変動が大きいと, 高血圧性心血管障害の発病率 が高く，あるいは，情動反応による昇圧度が大きいほ ぞ, 末梢血白血球数の増加が著しく, 藏器障害のリス クが高まるという報告がある(坂本 1993 , Tsuchiha shi T ら 1990)ので, 訓練中の血圧管理は重要と思わ れる.

以上から, 本研究結果と先行研究結果とを照合する と, 言語訓練中の心理的ストレスに敏感な患者のチェ ック機能は必要であり, 脳卒中後, 慢性期に言語訓練 を受けている患者の中で, 訓練中の血圧上昇に注意す べき患者像としては, まずコミュニケーション理解能 力のよく保たれている患者であること, 次に, 高血圧 であること，ということになると考えられる。これら の要件を満たす患者に対しては，自動血圧計による訓 練中の血圧測定を定期的に繰り返して実施することが 望ましい.そして，訓練中の収縮期血圧が $200 \mathrm{mmHg}$ 前後を推移するような場合には，その結果を主治医に 報告し，極端な血圧上昇が起こらないように降圧療法 の強化を図る。
言語訓練患者の血圧モニタリングの研究は少なく, 本研究で認められた言語訓練中の血圧上昇が, 言語障 害の回復過程や長期的予後にどのような影響があるか は不明である。しかし，言語訓練中に血圧が上昇する 患者に対しての血管性疾患予防のために, 訓練中の血 圧管理はきわめて重要と認識させられた。

今後は, 本研究の対象者に対する追跡調查を行うと 同時に, 症例数を増やして結果を整理する作業を進め ていきたい. なかでも, 本研究で血圧変動の再現性を 検討できたのが, 対象 21 例のうち, 冒頭で紹介した純 粋発語失行症の 1 例のみであったので, この点につい ては詳細な検討を加えるつもりである。また, 言語療 法士が男性の場合と女性の場合とで患者の血圧変動に 差があるか否か, さらに，訓練中の極端な血圧上昇を 抑制するのにどの種類の降圧薬が有効かなどの問題も 取り上げたい.

\section{ま と め}

1. 言語訓練を受けている慢性期脳血管障害患者 21 例に対し，血圧測定を実施し言語訓練中の血圧変動に ついて検討した。

2 。血圧上昇群は, 非上昇群よりも, WAB 失語症検 查得点率が高かった。

3 . 流暢性と構成課題の得点率は両群間で差がなか った.

4. 言語療法士が観察的に評価するコミュニケーシ ヨンレベルでは, 理解レベルで血圧上昇群のほうが軽 症だった。

5. 血圧・心拍数の大きな変動は高血圧性血管障害 をきたしやすく，言語訓練中に血圧が上昇する患者に 対しての血管性疾患予防のために，血圧管理は重要と 考えられた。

\section{文献}

1）加勢田美恵子, 木檜 晃, 伊佐地隆, 他：言語障 害を伴う片麻痺患者のストレスについての分析一 特に言語訓練が与えるストレスについて.第 32 回 日本リハビリテーション医学会学術集会予稿集, 130, 1995.

2）杉下守弘：WAB 失語症検査 (日本語版)。医学書 院，東京，1986.

3）杉下守弘：失語の診かた, CLINICAL NEUROSCIENCE，3 (5): 576-578, 1985.

4）小俣文子, 杉下守弘, 牧下英夫, 他：短縮版 WAB 失語症検査。神経内科, $30(2): 1989$.

5）菊地長徳：循環器内科, CLINICAL NEURO- 
SCIENCE, 12 (5) : 542-545, 1994.

6) Sakamoto, H., Imataka, K., Nishimura, H., et al. : Hematological and pressor hormone response to mental stress in essential hypertensive patients : a comparison with isometric handgrip exercise. Hypertens Res 15 : 33-39, 1992.

7）坂本浩之助：本態性高血圧患者の心理的ストレス 負荷および等尺性ハンドグリップ負荷による末梢 血液細胞数の変動. 北関東医学, 43(6): 637-646, 1993.

8）大畠明子，杉本啓子，寺田博子，他：急性期言語 療法のリスク管理.第 17 回日本失語症学会総会抄 録, $115,1993$.

9）大畠明子, 杉本啓子, 寺田博子, 他：失語症患者 のリスク管理（第 2 報）。第 19 回日本失語症学会 総会抄録, 101，1995。

10）芦田映直：白衣高血圧. 尾前照雄監修，血圧モ二 タリングの臨床. 医学書院, 東京, 52-56 頁, 1986.
11）持田 学, 坂本浩之助, 谷 哲夫, 他：言語障害 患者の言語訓練でみられた白衣現象 (white coat phenomenon）一言語療法士との対面訓練と患者 による自主訓練との比較. 群馬医学, $61 ： 89-94$, 1994.

12）坂本浩之助, 谷 哲夫, 菅井芳郎, 他：脳卒中患 者の言語訓練でみられた白衣現象一言語訓練士と の対面訓練と自主訓練との比較. Therapeutic Research, 16 (11) : 111-118, 1995.

13) Tsuchihashi, T., Abe, I., Tsukashima., A., et al. : Effects of meals and physical activity on blood pressure variability in elderly patients. A preliminary study. Am. J. Hypertens, 3 : 943-946, 1990.

別刷請求先 : $\mathbf{\tau} 370$ 高崎市中尾町 886

日高病院リハビリテーションセンター言語療法室 谷 哲夫 